\title{
TABLES, FIGURES, AND BOXES
}

\section{TABLES}

2.1. A political typology of default 46

2.2. Definitions of the different types of default 47

6.1. The three historical waves of default 96

7.1. List of sovereign defaults during the Great Depression 112

9.1. Exposure of top-6 U.S. banks to Mexico 140

10.1. Exposure of Mexican banks to Mexico 150

11.1. Comparison between the crises of the 1930s and 1980s 169

14.1. Consolidation and internationalization of Argentine banks 196

14.2. Outcome of 2001 midterm elections compared to 1997201

15.1. Comparison between the Mexican and Argentine crises 222

17.1. Foreign claims on Eurozone periphery in third quarter of 2009236

19.1. Reduction of foreign claims on Greece 263

19.2. Comparison between the debt crises in Mexico and Greece 273

20.1. Comparison between the debt crises in Argentina and Greece 297

\section{FIGURES}

0.1. Gross world public debt, 1980-2016 3

0.2. Gross world public debt/GDP ratio, 1980-2016 3

0.3. Share of countries in a state of default, 1800-1971 6

0.4. Share of world public debt in default, 1980-2016 8

1.1. Low- and middle-income countries' interest payments on external debt, 1970-2015 22

1.2. Reputation hypothesis 24

1.3. Legal sanctions hypothesis 27

1.4. Trade sanctions hypothesis 30

1.5. Democratic advantage hypothesis 33

1.6. Spillover costs hypothesis 38

2.1. Number of sovereign debt restructurings, 1970-2010 48

3.1. U.S. bank assets as a share of total industry assets, 1970 vs. 201062

3.2. Concentration of U.S. banking system, 1933-2008 63

3.3. Total IMF credit and loans outstanding, 1948-2015 65

3.4. Gross government debt of selected OECD countries, 1970-2011 66 
3.5. External government debt of low- and middle-income countries, 1970-2015 66

4.1. First enforcement mechanism of market discipline 75

4.2. Second enforcement mechanism of conditional lending 78

4.3. Third enforcement mechanism of internalized discipline 82

7.1. Share of marketable debt in central government debt, 1900-2011 120

7.2. Share of countries with a banking crisis, 1900-2008 121

7.3. BIS banks' total cross-border liabilities in foreign currencies, 1973-1981 122

8.1. External debt stocks of Latin America and the Caribbean, 1970-1983 129

8.2. External debt stock of Mexico and Latin America, 1970-1983 129

8.3. Average real interest rate on developing country floating debt, 1977-1983 130

8.4. Mexico's interest payments on external debt as a share of GNI, 1970-1982 132

8.5. Mexico's short-term debt as a share of total external debt stock, 1970-1982 132

8.6. Mexico's reserves as a share of total external debt, 1971-1982 133

8.7. The first enforcement mechanism in Mexico 136

9.1. Composition of Mexico's external debt in 1983139

9.2. G10+ commercial banks' exposure to Mexico, 1978-1985 139

9.3. Total use of IMF credit, 1970-1990 143

9.4. The second enforcement mechanism in Mexico 146

10.1. Leverage of Mexican banks, 1977-1982 150

10.2. Composition of the Mexican banking market in December 1980152

10.3. The third enforcement mechanism in Mexico 157

11.1. Net financial transfers from Global North to South, 1980-1989 165

11.2. Latin America's external debt as a share of GDP, 1978-1987 166

12.1. Bond issuance supplants bank lending, 1970-2013 175

12.2. Total external debt of low- and middle- income countries, 1970-1999 176

12.3. Argentina's total external debt, 1970-1999 176

12.4. Argentina's interest payments as share of public expenditures, 1990-2002 177

12.5. Argentine bonds' risk-spread (riesgo país) over U.S. Treasuries, 1998-2002 178

12.6. Argentina's access to private sources of financing, 1995-2001 182

12.7. Argentina's net capital flows, 1995-2002 183

12.8. The first enforcement mechanism in Argentina 184

13.1. Low- and middle-income countries' use of IMF credit, 1970-2002 186

13.2. Use of IMF credit by selected countries, 1990-2002 188

13.3. Argentina's use of IMF credit, 1970-2001 189 
13.4. Ownership of Argentina's $\$ 82$ billion privately held debt at time of default 191

13.5. The second enforcement mechanism in Argentina 193

14.1. Frequency of strikes in Argentina, 1999-2001 200

14.2. Change in bank deposits in Argentina, 1996-2001 202

14.3. The third enforcement mechanism in Argentina 205

15.1. Interbank rate in Argentina, 2000-2004 207

15.2. Argentina's GDP growth, 1998-2005 208

15.3. Argentina's unemployment rate, 1998-2005 208

15.4. Poverty levels in Argentina, 2001-2005 209

15.5. Argentina's current account balance, 1998-2005 216

15.6. Argentina's trade balance, 1998-2005 216

15.7. Argentina's exports by sector, 2001-2005 217

15.8. Total reserves in months of imports, Argentina vs. Mexico 217

16.1. Greece's budget deficit as a share of GDP, 1970-2009 226

16.2. Greece's gross government debt as a share of GDP, 1995-2010 226

16.3. EU countries' central government debt as a share of GDP, 1995-2010 227

16.4. Greece's credit rating vs. borrowing costs (2009-2015) 232

16.5. Rising spread on Greece's 10-year government bond yields, 1998-2011 233

16.6. The first enforcement mechanism in Greece 234

17.1. Bank holdings of Greek sovereign debt by country on April 30, 2010236

17.2. Value of new nonconcessional IMF lending commitments, 1952-2011 238

17.3. IMF growth projections vs. Greece's actual growth rate, 2009-2015 244

17.4. Total corporate and household deposits in Greek banks, 2001-2012 246

17.5. Weekly ECB bond purchases through SMP, May 2010-Jan 2011248

17.6. The second enforcement mechanism in Greece 249

18.1. Share of Greek government bonds held by domestic banks, 2008-2011 254

18.2. Bank concentration in Greece, 2005-2015 255

18.3. The third enforcement mechanism in Greece 259

19.1. Foreign banks' consolidated exposures to Greece, 2005-2013 262

19.2. Greece's public debt profile pre- and post-PSI 267

19.3. Where did the Greek bailout money go? 268

20.1. Comparison of Greece's output loss vs. U.S. Great Depression 277

20.2. Greece's and Eurozone's long-term unemployment rate, 2007-2014 277

20.3. Greece's youth unemployment rate (by age group), 2007-2015 278

20.4. Share of the population experiencing severe deprivation, 2007-2014 278 
$x$ - List of Tables, Figures, and Boxes

20.5. Public trust in Greece's political institutions, 2005-2012 279

20.6. Long-term Greek government bond yields (10-year), Jan 2014-Jul 2015283

20.7. Greece's Target 2 balance as indicator of capital flight, Jan 2014-Jul 2015284

20.8. Total corporate and household deposits in Greek banks, Jan 2014-Jul 2015284

20.9. Greece's official-sector repayment schedule for 2015286

20.10. Central bank funding (including ELA) to Greek banks, Jan 2010-Jul 2015289

\section{BOXES}

0.1. The three enforcement mechanisms of debtor compliance 11

4.1. Conditions under which enforcement mechanisms are effective 69

4.2. Conditions under which enforcement mechanisms break down 70 